\title{
Pengaruh Model Pembelajaran Learning Cycle terhadap Kualitas Proses, Hasil Belajar dan Retensi Hasil Belajar Siswa pada Materi Pokok Asam Basa
}

\author{
Fatimah Zahri ${ }^{1}$ \\ ${ }^{1}$ Pendidikan Kimia-Universitas Negeri Malang
}

\section{INFO ARTIKEL}

\section{Riwayat Artikel:}

Diterima: 11 Juni 2018

Disetujui: 7 Oktober 2018

\section{Kata kunci:}

Hasil belajar

Model pembelajaran

Rancangan deskriptif

Eksperimen semu

\author{
Alamat Korespondensi: \\ Fatimah Zahri \\ Pendidikan Kimia \\ Universitas Negeri Malang \\ Jalan Semarang 5, Malang 65154 \\ E-mail: fatimahz@yahoo.co.id
}


Pembelajaran kimia di kelas XI IPA SMAN 1 Indrapuri Aceh Besar Proprinsi NAD masih belum memuaskan, karena hasil belajar kimia peserta didik baik dalam ranah kognitif, afektif maupun psikomotor masih rendah (di bawah standar ketuntasan minimal yang ditentukan guru). Standar ketuntasan minimal untuk ranah kognitif pada mata pelajaran kimia kelas XI IPA adalah 65. Hal ini antara lain disebabkan karena siswa beranggapan bahwa pelajaran kimia merupakan pelajaran yang sulit. Kesulitan belajar dan kesulitan memahami konsep yang muncul pada siswa kemungkinan disebabkan banyaknya konsep kimia yang harus dikuasai, selain itu dalam ilmu kimia selain mempelajari fakta, juga banyak melibatkan perhitungan matematika. Pada umumnya kesulitan yang dihadapi siswa adalah dalam pemecahan soal-soal yang mereka temui dalam proses pembelajaran kimia.

(Mackinnu, 1996) mengemukakan bahwa timbulnya kesulitan siswa dalam memahami konsep-konsep kimia pada umumnya bukan hanya disebabkan keabstrakan konsepnya tetapi juga berasal dari ketidakmampuan guru menghadirkan metode pembelajaran yang tepat, dan guru kurang mampu memotivasi serta melibatkan siswa dalam proses pembelajaran. Metode pengajaran yang terbaik dengan sendirinya adalah yang mengutamakan subjek didik dalam proses pemahaman konsep-konsep, bukan lagi pada guru yang membuat siswa mengerti akan konsep-konsep tersebut. Mengingat semakin tingginya tuntutan masyarakat terhadap mutu layanan pendidikan, maka guru perlu mengembangkan pendekatan atau strategi dalam proses pembelajaran dengan memgimplementasikan berbagai model pembelajaran yang berorientasi pada filosofi konstruktivistik.

Model pembelajaran yang sesuai dengan pendekatan konstruktivistik, adalah model pembelajaran yang dapat membantu siswa untuk membangun pengetahuan sesuai dengan pengetahuan awal yang telah dimilikinya. Salah satu model pembelajaran yang sesuai dengan pendekatan kontruktivistik adalah model pembelajaran daur belajar (Learning Cycle). Di antara model daur belajar yang banyak digunakan adalah model daur belajar enam fase (Sixphase Learning Cycle) atau LC-6.

(Iskandar, 2009) mengembangkan daur belajar lima fase yang tahapannya sebagai berikut: fase ajakan (invitation/ engagement), eksplorasi (exploration), penjelasan (explanation), penerapan (elaboration), dan evaluasi (evaluation). Selanjutnya Johnston (Iskandar, 2009) menambah- kan satu fase pada daur belajar lima fase yaitu fase identifikasi kompetensi dasar oleh pengajar di awal pembelajaran sehingga disebut daur belajar enam fase. Fase-fase dalam daur belajar enam fase adalah sebagai berikut: identifikasi kompetensi dasar, undangan, eksplorasi, penjelasan, penerapan, dan evaluasi.

Dalam penelitian ini digunakan $L C-6$ yang merupakan salah satu dari strategi pembelajaran yang dapat diterapkan dalam topik-topik kimia yang bersifat teoritis maupun yang melibatkan praktikum Johnston dalam (Iskandar, 2009). Alasan peneliti menggunakan model pembelajaran LC-6 adalah karena model pembelajaran ini pada fase awal dimulai dengan fase identifikasi tujuan pembelajaran oleh pengajar sangat cocok diterapkan pada kelas pemula. Kecocokan ini disebabkan pada fase awal guru dapat membangkitkan motivasi belajar siswa sehingga lebih fokus pada materi pelajaran. Di samping itu pembagian waktu dan langkah-langkah diperjelas sehingga memudahkan untuk dilaksanakan dalam kegiatan pembelajaran kimia.

Dengan menggunakan model pengajaran yang tepat diharapkan dapat meningkatkan prestasi belajar siswa lebih baik, khususnya yang berkaitan dengan kemampuan guru menyediakan pengalaman belajar bagi siswa, karena suatu pendekatan pembelajaran memiliki pengaruh terhadap proses perolehan konsep bagi siswa. Mengingat materi asam dan basa banyak melibatkan konsep, prinsip, teori, aturan serta perhitungan secara matematis maka perlu diupayakan suatu metode pengajaran yang dapat memudahkan siswa memahami materi asam dan basa secara tuntas.

Model pembelajaran $L C$-6 memiliki fase-fase yang dapat mengkonstruksi pengetahuan. Pembelajar tidak diberi materi jadi, melainkan diberi kebebasan untuk mencoba-coba atau diberi kebebasan melakukan eksplorasi untuk menemukan suatu konsep. Pengalaman-pengalaman eksplorasi semacam ini membuat retensi pengetahuan akan lebih tersimpan di dalam struktur kognitif pembelajar, bila sewaktu-waktu diperlukan untuk dipanggil lagi (Iskandar, 2009).

Persepsi siswa diduga juga merupakan salah satu faktor yang dapat mempengaruhi keberhasilan pembelajaran. Perhatian, sikap siswa yang positif, serta siswa tertarik untuk mempelajari pembelajaran juga menyebabkan retensi hasil belajar siswa meningkat. Perasaan tertarik terhadap sesuatu yang sedang dipelajari akan mempengaruhi minat siswa (Winkel, 2007). Dengan demikian, perasaan tertarik terhadap model pembelajaran $L C-6$ akan mempengaruhi proses dan hasil belajar siswa. 


\section{METODE}

Penelitian ini menggunakan dua rancangan yaitu rancangan eksperimen semu (kuasi eksperimen) dan rancangan deskriptif. Rancangan deskriptif digunakan untuk mengamati proses pembelajaran siswa kelas XI IPA dengan menggunakan model pembelajaran $L C-6$ dan tanpa $L C-6$ pada pokok bahasan larutan asam basa, dalam kegiatan pembelajaran teori maupun praktikum di laboratorium, hasil belajar ranah psikomotor, ranah afektif dan persepsi siswa.

Rancangan eksperimen semu digunakan untuk mengkaji pemahaman siswa tentang materi larutan asambasa berupa tes hasil belajar ranah kognitif dan retensi hasil belajar siswa, khususnya tentang perbedaan hasil belajar dan retensi hasil belajar siswa dengan menggunakan model $L C$ - 6 dan tanpa $L C$ - 6 .

Tabel 1. Rancangan Hasil belajar dan Tes Retensi Pemahaman

\begin{tabular}{cccc}
\hline Subjek & Perlakuan & Hasil belajar & Retensi $^{*}$ \\
\hline $\mathrm{A}$ & $\mathrm{X}$ & $\mathrm{P}_{1}$ & $\mathrm{R}_{1}$ \\
$\mathrm{~B}$ & $\mathrm{Y}$ & $\mathrm{P}_{2}$ & $\mathrm{R}_{2}$ \\
\hline
\end{tabular}

Keterangan:

A = kelas eksperimen

$\mathrm{B}=$ kelas kontrol

$\mathrm{X}=$ perlakuan dengan model pembelajaran $L C-6$

$\mathrm{Y}=$ perlakuan model pembelajaran Konvensional

$\mathrm{P}=$ tes prestasi belajar I

$\mathrm{R}=$ tes retensi belajar I dan II

Waktu tes retensi I 2 minggu setelah hasil belajar dan tes retensi II setelah 4 minggu ( 1 bulan) setelah hasil belajar

Subjek penelitian ini adalah siswa kelas XI IPA SMAN 1 Indrapuri Aceh Besar Propinsi NAD tahun ajaran 2009/2010 yang terdiri dari dua kelas. Sebagai kelompok eksperimen adalah siswa kelas XI IPA ${ }^{1}$ dengan jumlah siswa sebanyak 27 orang yang diajar dengan menggunakan model pembelajaran $L C-6$ sedangkan kelas kontrol adalah siswa kelas XI IPA ${ }^{2}$ yang diajar dengan model konvensional yang juga terdiri dari 27 siswa. Variabel bebas dalam penelitian ini adalah model pembelajaran yang terdiri dari model pembelajaran $L C-6$ yang diterapkan pada kelompok eksperimen, dan metode konvensional diterapkan pada kelompok kontrol. Variabel terikat dalam penelitian ini adalah kualitas pembelajaran pada konsep larutan asam-basa yang ditunjukkan dari peningkatan aktivitas, hasil belajar dan retensi hasil belajar siswa. Peningkatan proses pembelajaran diamati melalui lembar observasi, hasil belajar dan retensi pemahaman siswa diukur berdasarkan skor yang diperoleh dari hasil belajar, tes retensi I dan tes retensi II.

Instrumen pengumpulan data dalam penelitian ini digunakan 5 macam yaitu lembar obsevasi, aktivitas mental, hasil belajar, tes retensi dan angket. Analisis data hasil observasi berupa analisis deskriptif kualitatif, teknik ini digunakan untuk menganalisis data sehingga memperoleh kesimpulan tentang proses belajar dalam menggunakan $L C$ - 6 , aktivitas mental siswa, hasil belajar ranah psikomotor, ranah afektif dan persepsi. Untuk data hasil belajar dan tes retensi hasil belajar digunakan uji $t$.

\section{HASIL}

\section{Hasil Belajar Siswa}

Berdasarkan uji prasyarat awal dengan bantuan program SPSS 15.0 for windows hasil tes pada kelas eksperimen dan kelas kontrol terdistribusi normal dan berada dalam kelompok homogen. Pada Tabel 2. terlihat bahwa skor rata-rata hasil belajar untuk konsep asam basa pada kelas eksperimen 70,2, sedangkan kelas kontrol memiliki rata-rata hasil belajar rata-rata sebesar 65,9. Pada Tabel 3 menunjukkan bahwa hasil belajar ranah psikomor berikut merupakan penilaian terhadap kinerja siswa pada saat eksperimen di laboratorium.

Hasil belajar ranah afektif dalam penelitian ini diperoleh dari sikap siswa terhadap pembelajaran yang dilakukan pada kegiatan praktikum di laboratorium disajikan dalam Tabel 4. Pada Tabel 4. menunjukkan bahwa secara umum hasil belajar siswa dalam ranah afektif yang diajar dengan model pembelajaran $L C-6$ lebih tinggi jika dibandingkan dengan kelas kontrol yang diajar dengan model konvensional. 
Tabel 2. Skor Rata-rata Hasil Belajar Ranah Kognitif untuk Konsep Larutan Asam-Basa

\begin{tabular}{cccccc}
\hline Hasil Belajar & N & Minimum & Maksimum & $\bar{x}$ & Sd \\
\hline Kelas Eksperimen & 27 & 50 & 85 & 70,2 & 8,1 \\
Kelas Kontrol & 27 & 55 & 80 & 65,9 & 6,5 \\
\hline
\end{tabular}

Tabel 3. Skor Rata-rata Hasil Belajar Ranah Psikomotor

\begin{tabular}{ccc}
\hline No & Kelas & $\bar{x}$ \\
\hline 1 & Eksperimen & 76,5 \\
2 & Kontrol & 72,5 \\
\hline
\end{tabular}

Tabel 4. Skor Rata-rata Hasil Belajar Ranah Afektif

\begin{tabular}{cccc}
\hline No & Kelas & $\bar{x}$ & Kriteria \\
\hline 1 & Eksperimen & 80,3 & B \\
2 & Kontrol & 76,6 & B \\
\hline
\end{tabular}

\section{Retensi Hasil Belajar Siswa}

Berdasarkan Tabel 5 perolehan rata-rata hasil belajar 70,2, setelah 2 minggu berselang, tes retensi I digelar kepada siswa yang memberikan hasil tes retensi rata-rata 68,0, dan setelah 4 minggu berselang dilakukan tes retensi II kepada siswa yang memberikan hasil tes retensi rata-rata 65,6. Hasil penelitian tes retensi I dan II secara ringkas dapat dilihat pada Tabel 5. Pada Tabel 6 dipaparkan ringkasan perolehan skor hasil belajar dan tes retensi, dimana proses pembelajaran dengan model konvensional. Hasil belajar rata-rata dicapai 65,9, tes retensi I yang dilaksanakan 2 mingggu setelah hasil belajar dilakukan diperoleh hasil rata-rata 59,4 dan retensi II yang dilaksanakan 2 minggu setelah tes retensi I didapat hasil rata-rata sekitar 55,9.

Tabel 5. Ringkasan Hasil Belajar, Tes Retensi I dan Retensi II Kelas Eksperimen

\begin{tabular}{cccc}
\hline No & Hasil & N & $\bar{x}$ \\
\hline 1 & Hasil belajar & 27 & 70,2 \\
2 & Tes retensi I & 27 & 68,0 \\
3 & Tes retensi II & 27 & 65,6 \\
\hline
\end{tabular}

Tabel 6. Ringkasan Hasil Belajar, Tes Retensi I dan Retensi II Kelas Kontrol

\begin{tabular}{cccc}
\hline No & Hasil & N & $\bar{x}$ \\
\hline 1 & Hasil belajar & 27 & 65,9 \\
2 & Tes retensi I & 27 & 59,4 \\
3 & Tes retensi II & 27 & 55,9 \\
\hline
\end{tabular}

\section{Proses Pembelajaran}

Hasil pengamatan tahap-tahap yang telah dilalui pada model pembelajaran LC-6. Secara keseluruhan tahapan proses pembelajaran model $L C$ - 6 berlangsung baik dengan total rata-rata skor 3,0 dari keseluruhan tahap pembelajaran dengan $L C-6$ (Tabel 7).

Tabel 7. Skor Rata-rata Kualitas Proses Pengelolaan Pembelajaran Model LC-6

\begin{tabular}{lccc}
\hline No & Aspek yang Teramati & Skor Rata-rata & Kategori \\
\hline 1. & Tahap I: Identifikasi tujuan pembelajaran & & \\
& a. Persiapan & 3,1 & \\
& b. Menginformasikan tujuan pembelajaran & 2,9 & \\
c. Memotivasi & 2,9 & Cukup baik \\
Rata-rata & 2,9 & \\
$2 . \quad$ Tahap II: Fase engagement (undangan) & 3 & \\
& a. Mengakses pengetahuan awal siswa & 3 & \\
& b. Mengajukan pertanyaan &
\end{tabular}




\begin{tabular}{|c|c|c|c|}
\hline & Rata-rata & 3 & Baik \\
\hline \multirow[t]{5}{*}{3.} & Tahap III: Eksplorasi pengetahuan siswa & & \\
\hline & a. Mengecek pemahaman siswa & 2,8 & \\
\hline & $\begin{array}{l}\text { b. Memberi kesempatan untuk mengeksplorasi } \\
\text { sumber informasi }\end{array}$ & 3,1 & \\
\hline & $\begin{array}{l}\text { c. Mempersiakan peralatan dan bahan-bahan } \\
\text { laboratorium }\end{array}$ & 4 & \\
\hline & Rata-rata & 3,3 & Baik \\
\hline \multirow[t]{5}{*}{4.} & Tahap IV: Eksplanasi (penjelasan) & & \\
\hline & a. Memberikan nama/istilah dari konsep & 3 & \\
\hline & b. Membantu siswa mengorganisasikan data & 3 & \\
\hline & c. Memberikan penegasan konsep & 3 & \\
\hline & Rata-rata & 3 & Baik \\
\hline \multirow[t]{4}{*}{5} & Tahap V: Elaborasi (penerapan) & & \\
\hline & a. Mendiskusikan konsep-konsep penting & 3 & \\
\hline & b. Konsep diperluas pada konteks dan situasi baru & 2,5 & \\
\hline & Rata-rata & 2,8 & Cukup baik \\
\hline \multirow[t]{5}{*}{6} & Tahap VI: Evaluasi & & \\
\hline & a. Mengajukan pertanyaan & 3 & \\
\hline & b. Memberikan LKS & 3 & \\
\hline & Rata-rata & 3 & Baik \\
\hline & Total rata-rata skor & 3,0 & Baik \\
\hline
\end{tabular}

Hasil pengamatan pada tahapan yang dilalui dari model konvensional yang dipaparkan pada Tabel 8 .

Tabel 8. Skor Kualitas Proses Pengelolaan Model Pembelajaran Konvensional

\begin{tabular}{|c|c|c|c|}
\hline No & Aspek yang Diamati & Skor Rata-rata & Kategori \\
\hline \multirow[t]{3}{*}{1.} & Persiapan & 3 & Baik \\
\hline & Pelaksanaan & & \\
\hline & a. Pendahuluan & & \\
\hline \multirow{14}{*}{2} & 1) Menginformasikan tujuan pembelajaran & 2,8 & \\
\hline & 2) Memotivasi siswa & 2,5 & \\
\hline & 3) Mengaitkan pembelajaran sebelumnya & 2,6 & \\
\hline & Rata-rata & 2,6 & Cukup baik \\
\hline & b. Kegiatan Inti & & \\
\hline & 1) Mempresentasikan materi & 3 & \\
\hline & 2) Mempergunakan media pembelajaran & 3 & \\
\hline & 3) Mengarahkan diskusi & 3 & \\
\hline & Rata-rata & 3 & Baik \\
\hline & c. Interaksi guru-siswa & 2,3 & Cukup baik \\
\hline & d. Kegiatan Laboratorium & & \\
\hline & 1) Mempersiapkan alat dan bahan praktikum & 3,5 & \\
\hline & 2) Membantu mengorganisasikan data & 3 & \\
\hline & Rata-rata & 3,3 & Baik \\
\hline \multirow[t]{2}{*}{3.} & Penutup & 3 & Baik \\
\hline & Total rata-rata skor & 2,9 & Cukup baik \\
\hline
\end{tabular}

Secara keseluruhan kualitas proses pembelajaran berlangsung cukup baik dengan rata-rata skor 2,9. 
Aktivitas Mental

Rata-rata hasil aktivitas mental secara ringkas dapat dilihat pada Tabel 9. berikut:

Tabel 9. Hasil Rata-rata Aktivitas Mental Siswa Model Pembelajaran LC-6

\begin{tabular}{ccc}
\hline Fase & Indikator & Jumlah Siswa (\%) \\
\hline I. Identifikasi & Tahu tujuan pembelajaran & 27 siswa (100\%) \\
tujuan & Tidak tahu tujuan pembelajaran & 0 siswa $(0 \%)$ \\
Pembelajaran & Tahu dari guru & 24 siswa $(85,2 \%)$ \\
II. Engegament & Tahu materi pembelajaran & 24 siswa $(85,2 \%)$ \\
& Tahu dari guru & 16 siswa $(59,3 \%)$ \\
III. Eksplorasi & Tertarik untuk belajar & 24 siswa $(85,2 \%)$ \\
& Waktu untuk menggali informasi & $75 \%$ dari 20 menit \\
IV. Eksplanasi & Pemahaman materi dari literatur & Hanya 50\% paham \\
& Denyimpulkan hasil bacaan & 18 siswa (66,7\%) \\
V. Elaborasi & Pemat menjelaskan dengan kata-kata sendiri & 19 siswa $(70,4 \%)$ \\
& Dapat sedikit mengaplikasikan konsep & 22 siswa (81,5\%) paham sebagian \\
VI. Evaluasi & Waktu yang tersedia cukup untuk menjawab LKS & 17 siswa $(63 \%)$ \\
& Paham konsep & 22 siswa (81,5\%) \\
& Dapat menjawab soal & 11 siswa $75 \%$ paham \\
\hline
\end{tabular}

\section{Persepsi Siswa}

Persentase persepsi rata-rata siswa terhadap model pembelajaran $L C-6$ sebesar $70,2 \%$, berada pada kategori setuju (positif) terhadap model pembelajaran yang digunakan pada konsep larutan asam basa.

Tabel 10. Persepsi Siswa Kelas Eksperimen

\begin{tabular}{cccccc}
\hline No & Variabel & No. Angket & $\begin{array}{c}\text { Skor } \\
\text { Total }\end{array}$ & $\begin{array}{c}\text { Skor } \\
\text { Rata-rata }\end{array}$ & Persentase (\%) \\
\hline 1 & Senang belajar & $1,2,4,8,18$ & 454 & 3,36 & 67,2 \\
& & & & \\
2 & Mudah memahami & $3,5,9,11$ & & 3,73 & 74,6 \\
& materi pelajaran & & 403 & & \\
3 & Termotivasi untuk belajar & 6,16 & 229 & 4,24 & 84,8 \\
4 & Termotivasi untuk menjawab soal & 7,13 & 169 & 3,13 & 62,6 \\
5 & Dihargai dan berani mengeluarkan pendapat & $10,14,17$ & 292 & 3,60 & 72 \\
6 & Kerjasama dengan teman & 12,19 & 174 & 3,22 & 64,4 \\
7 & Mandiri dalam belajar dan bekerja & 15,20 & 178 & 3,30 & 66 \\
& $\bar{x}$ & & & & 70,2 \\
\hline
\end{tabular}

Persepsi siswa yang diajar dengan metode konvensional pada kelas kontrol dapat dilihat pada Tabel 11.

Tabel 11. Persepsi Siswa Kelas Kontrol

\begin{tabular}{lccccc}
\hline No & Variabel & No. Angket & Skor Total & $\begin{array}{c}\text { Skor } \\
\text { Rata-rata }\end{array}$ & $\begin{array}{c}\text { Persentase } \\
(\%)\end{array}$ \\
\hline 1 & & & 454 & 2,81 & 56,2 \\
2 & Senang belajar & $1,2,4,8,18$ & & 3,06 & 61,2 \\
& $\begin{array}{c}\text { Mudah memahami } \\
\text { materi pelajaran }\end{array}$ & $3,5,9,11$ & 403 & & \\
3 & Termotivasi untuk belajar & 6,16 & 229 & 2,93 & 58,6 \\
4 & Termotivasi untuk menjawab soal & 7,13 & 169 & 3,10 & 62 \\
5 & Dihargai dan berani mengeluarkan pendapat & $10,14,17$ & 239 & 2,83 & 56,6 \\
6 & Kerjasama dengan teman & 12,19 & 148 & 2,74 & 54,8 \\
7 & Mandiri dalam belajar dan bekerja & 15,20 & 178 & 3,00 & 60,0 \\
& & & & & 58,6 \\
\hline
\end{tabular}


Persentase persepsi rata-rata siswa terhadap pembelajaran model konvensional sebesar $58,6 \%$ berada pada kategori netral, hal ini berarti siswa netral terhadap model konvensional yang digunakan pada konsep larutan asam basa.

\section{PEMBAHASAN}

\section{Hasil Belajar}

Strategi pembelajaran merupakan salah satu faktor pendukung keberhasilan pendidikan, dan hal ini sangat tergantung pada kemampuan guru dalam merancang model pembelajaran. Model pembelajaran $L C-6$ merupakan salah satu alternatif yang dapat digunakan untuk meningkatkan hasil belajar siswa, karena dengan menggunakan model pembelajaran $L C-6$ siswa lebih banyak dilibatkan dalam proses belajar mengajar.

Penggunaan model pembelajaran $L C$ mampu meningkatkan kualitas proses dan hasil belajar, karena siswa terlibat langsung dalam melakukan kegiatan praktikum. Kemudian siswa diberikan kesempatan untuk berperan aktif dalam pembelajaran. Hal ini membuktikan bahwa $L C$ - 6 sebagai model pembelajaran dapat dilaksanakan dengan memberikan lingkungan yang mendukung terjadinya proses belajar kontruktivistik. Kesinambungan proses-proses pengenalan konsep, eksplorasi, penjelasan , dan aplikasi dapat dijaga sehingga pengetahuan siswa dapat dibangun sedikit demi sedikit, diperkuat, dan dilanjutkan (Brown \& Abell, 2007).

Ranah psikomotorik adalah ranah yang berkaitan dengan keterampilan (skill) atau kemampuan bertindak setelah seseorang menerima pengalaman belajar tertentu. Tujuan-tujuan psikomotor adalah tujuan-tujuan yang banyak berkenaan dengan aspek keterampilan motorik atau gerak dari peserta didik atau siswa. Hasil belajar psikomotor ini sebenarnya merupakan kelanjutan dari hasil belajar kognitif dan hasil belajar afektif (Sagala, 2010).

Hal ini terjadi karena pada kelas $L C-6$ siswa aktif dan antusias selama proses pembelajaran berangsung. Model pembelajaran $L C$ - 6 memberikan kemerdekaan pada siswa untuk mengkonstruksi sendiri pengetahuan dibenak mereka. Siswa telah menyadari bagaimana mereka harus belajar. Keaktifan siswa dapat terlihat mulai awal proses pembelajaran, siswa nampak bertanggung jawab pada pembelajaran. Relevan dengan yang disampaikan oleh (Nur \& Wikandari, 2000) bahwa dengan pembelajaran yang mengacu pada konstruktivisme memberikan peluang kepada siswa untuk bertanggung jawab terhadap pembelajarannya sendiri dan bersifat mandiri.

Tujuan hasil belajar ranah afektif banyak berkaitan dengan aspek perasaan, nilai, sikap, dan minat perilaku peserta didik. Sikap seseorang dapat diramalkan perubahanya apa bila ia telah memiliki penguasaan kognitif tingkat tinggi. Ciri-ciri belajar afektif akan tampak pada siswa dalam berbagai tingkah laku, seperti perhatiannya terhadap pelajaran, etika dan moral yang akan meningkatkan kedisiplinan dalam mengikuti pelajaran lainnya (Sagala, 2010). Selain itu tipe hasil belajar afektif tampak pada siswa dalam berbagai tingkah laku seperti motivasi belajar, menghargai guru dan teman, kebiasaan belajar, dan hubungan sosial (Sudjana, 2014).

Hal ini berarti baik kelompok kontrol maupun kelompok eksperimen rata-rata nilai afektifnya dapat dikatagorikan baik, sehingga mereka memiliki rasa tanggung jawab baik secara individu dan dalam kelompok, dapat bekerjasama dalam kelompok, menghargai pendapat orang lain. Karena pada dasarnya setiap manusia memiliki potensi yang dapat dikembangkan menjadi kemampuan untuk hidup dimasyarakat. Keberhasilan pembelajaran pada ranah kognitif dan psikomotorik juga dipengaruhi oleh kondisi afektif siswa. Dengan demikian jika kita mengetahui ranah afektif peserta didik dengan tepat, maka kita dapat menerapkan strategi pembelajaran yang tepat kepada siswa.

\section{Retensi Hasil Belajar}

Pengujian hasil belajar melalui retensi yang dilaksanakan selang waktu 2 minggu dan 4 minggu dari proses pembelajaran, dilakukan untuk mengetahui seberapa besar dampak dari model pembelajaran yang konstruktivis pada ketahanan atau kemampuan daya ingat siswa terhadap pesan pembelajaran. kemampuan ini dapat diidentifikasi dari keterampilan menyebut kembali, memilih, mengidentifikasi, membedakan, memperkirakan, dan menjelaskan kembali (Pranata, 2006).

Tingginya perbedaan rata-rata kelompok $L C-6$ dibandingkan model konvensional, dikarenakan penataan lingkungan belajar yang mendorong terjadinya konstruksi kognisi sehingga lebih mampu memahami makna pesan pembelajaran. Pembelajaran konstruktivistik memberikan dampak terhadap ketahanan/retensi atau 
kemampuan daya ingat siswa pada pesan pembelajaran. Secara alamiah siswa adalah pemikir yang aktif dan pembelajar yang aktif membangun pemahamannya atau mengembangkan makna setelah mendapatkan rangsangan dari indra sensorik seperti pendengaran, penglihatan dan perabaan (Ibnu, 2005).

\section{Proses Pembelajaran}

Pendidikan dan pengajaran dikatakan berhasil apabila terjadi perubahan-perubahan akibat dari proses belajar mengajar yang dialaminya. Setidak-tidaknya, apa yang dicapai siswa merupakan akibat dari proses yang ditempuhnya melalui program dan kegiatan yang dirancang dan dilaksanakan oleh guru dalam proses pengajaran (Sudjana, 2014).

Hal ini menunjukkan siswa secara aktif dilibatkan dalam pengorganisasian dan penemuan informasi (pengetahuan). Semakin aktif siswa maka ketercapaian ketuntasan pembelajaran semakin besar, sehingga semakin efektif pula pembelajaran. Relevan dengan hasil penelitian (Budiasih \& Widarti, 2009; Iskandar, 2009; Rubianus, 2012) bahwa $L C$ dapat meningkatkan kualitas pembelajaran. Aktivitas siswa pada proses pada saat siswa mengeksplorasi pengetahuannya melalui membaca literatur atau pembuktian hipotesis saat praktikum dan mengerjakan LKS sangat padat.

\section{Aktivitas Mental}

Aktivitas belajar yang dimaksud adalah aktivitas yang bersifat fisik maupun mental. Dalam kegiatan belajar ke dua aktivitas itu harus selalu berkaitan. Sebagai contoh seseorang sedang belajar dan membaca. Secara fisik kelihatan bahwa orang tersebut membaca menghadapi buku, tetapi mungkin pikiran dan sikap mentalnya tidak tertuju pada buku yang dibacanya. Ini menunjukkan tidak ada keserasian antara aktivitas fisik dengan aktivitas mental. Kalau demikian, maka belajar itu tidak akan optimal (Sardiman, 2010).

Gambaran umum proses kognitif atau pikiran manusia bekerja dapat diasumsikan sebagai berikut: proses kognitif cenderung lebih aktif, yang dapat dilihat dari rasa ingin tahu, mengajukan pertanyaan. Proses kognitif cenderung lebih efektif ketika menangani informasi positif dari pada negatif, kebanyakan orang cenderung lebih mengingat informasi positif daripada informasi negatif. Proses kognitif juga dipengaruhi oleh emosi yang tengah dialami seseorang. Misalnya di dalam belajar, mengingat, membuat keputusan atau memecahkan masalah, dapat dilakukan dengan lebih efektif ketika seseorang sedang bergembira daripada bersedih (Suharnan, 2005).

\section{Persepsi Siswa}

Persepsi siswa merupakan salah satu faktor yang mempengaruhi keberhasilan pembelajaran karena persepsi siswa akan menentukan bagaimana siswa mempelajari dan memahami suatu materi pelajaran. Persepsi siswa yang positif terhadap pembelajaran akan mendorong siswa untuk belajar sungguh-sungguh, menyelesaikan tugas dengan baik serta memperhatikan pelajaran di kelas. Menurut (Winkel, 2007) menyatakan bahwa siswa yang merasa senang akan bergairah dan bersemangat dalam belajar.

Dari penjelasan di atas dapat ditarik kesimpulan dengan melibatkan siswa dalam proses belajar mengajar, mengakibatkan siswa cenderung bersemangat dan antusias mengikuti pelajaran. Ini dapat dilihat dari motivasi siswa dalam mengerjakan LKS, mengajukan pertanyaan, dapat berkerja mandiri maupun kelompok, sehingga dapat mengembangkan keterampilan ilmiah dan keterampilan sosial. Keterampilan ilmiah siswa yang berkembang antara lain berupa keterampilan siswa dalam mengamati, mengumpulkan data, menggunakan alat dan bahan dalam kegiatan laboratorium serta mampu mengkomunikasikan data percobaan.

Berdasarkan hasil penelitian ini dapat dijelaskan bahwa secara umum siswa masih belum setuju sepenuhnya apabila metode konvensional digantikan dengan model pembelajaran yang lain secara umum siswa menyatakan metode konvensional boleh saja digunakan. Mungkin selama ini guru hanya menggunakan model konvensional yang sudah terbiasa mereka terima sehingga tidak terpengaruh terhadap persepsinya. Kemungkinan lain yang menyebabkan siswa merespon netral terhadap model konvensional karena siswa belum mengetahui model pembelajaran yang lain selain model konvensional, sehingga siswa sulit untuk menentukan persepsi. Selain itu juga dikarenakan dengan model konvensional siswa sudah merasa nyaman untuk mendengarkan penjesan pengajar sambil mencatat ringkasan yang didektekan oleh pengajar.

Dari penjelasan di atas dapat ditarik kesimpulan, selama ini guru hanya menggunakan model konvensional dan kurang menvariasikan model pembelajaran sehingga siswa akan merespon secara netral. Guru 
mempunyai peran yang sangat penting dalam pemilihan strategi pembelajaran yang tepat agar pembelajaran menjadi menarik dan menyenangkan serta menumbuhkan sikap positif siswa. Hal ini berarti bahwa hasil suatu persepsi atau interpretasi mengenai suatu stimulus akan ditentukan oleh kombinasi antara sifat-sifat yang ada pada stimulus yang dipersepsikan itu dengan pengetahuan yang tersimpan di dalam ingatan seseorang yang relevan dengan stimulus itu (Suharnan, 2005). Dengan demikian hasil belajar siswa diharapkan akan menjadi lebih baik.

\section{Perbandingan Hasil-hasil Penelitian Tentang Model Pembelajaran LC}

Penelitian yang dilakukan oleh (Maysara, 2006) tentang keefektifan model pembelajaran $L C$ ditinjau dari prestasi belajar dan persepsi siswa untuk topik laju reaksi pada siswa kelas II SMAN 4 Kendari, menyatakan bahwa prestasi belajar siswa yang diajar dengan LC-5 lebih baik dari prestasi belajar siswa yang diajar dengan model pembelajaran $L C$-3 dan konvensional pada materi laju reaksi kimia. Persepsi siswa terhadap model pembelajaran $L C$ adalah positif $(73,2 \%)$ dan netral $(57,7 \%)$ terhadap metode ceramah. Kelebihan dari penelitian ini sampel yang digunakan lebih banyak yaitu 3 kelas yang diberi perlakuan yang berbeda. Materi laju reaksi dalam pembelajaran kimia merupakan materi yang tersusun dari konsep-konsep abstrak, melibatkan perhitungan matematika serta saling terkait antara konsep yang satu dengan konsep yang lain. Selain itu pada materi laju reaksi juga dapat dilakukan praktikum. Sehingga selain hasil belajar ranah kognitif dapat juga diukur hasil belajar ranah psikomotor dan afektif. Keberhasilan pembelajarn tidak hanya ditentukan oleh hasil belajar saja, seharusnya juga memperhatikan proses pembelajaran.

(Kartini, 2007) meneliti keefektifan pembelajaran menggunakan model pembelajaran LC-5 dan Diagram alir untuk meningkatkan hasil belajar siswa di SMA Laboratorium Universitas Negeri Malang pada konsep stoikiometri larutan dan larutan penyangga. Pada penelitian ini telah dipadukan $L C-5$ dengan diagram alir sehingga hasil belajar untuk larutan penyangga meningkat pada ranah afektif dan psikomotor, sedangkan untuk hasil belajar ranah kognitif relatif tidak berubah. Sementara itu penelitian pada materi stoikiometri larutan terjadi peningkatan hasil belajar baik ranah kognitif, psikomotor maupun afektif. Tetapi penelitian ini tidak melihat proses yang terjadi selama pembelajaran.

Penelitian lainnya yang dilakukan oleh (Sadiqin, Istyadji, \& Winarti, 2017) tentang penerapan paduan model pembelajaran $L C-5$ dengan kooperatif group investigation untuk meningkatkan kualitas proses dan hasil belajar siswa SMA pada materi pokok larutan elektrolit dan nonelektrolit. Paduan model ini telah memberikan dampak yang sangat signifikan terhadap peningkatan hasil belajar dibandingkan dengan model konvensional. Tepi tidak ada perbedaan hasil belajar antara kelompok yang diajar model $L C-5$ dengan $L C-5$ yang dipadu dengan group investigation. Hasil belajar kognitif meningkat juga disebabkan karena telah menyediakan buku teks bahan ajar yang berperan sebagai media pembelajaran. Namun demikian penelitian ini tidak memperhatikan ranah psikomotor dan ranah afektif pada hal materi larutan elektrolit dan non elektrolit juga dapat melibatkan ranah psikomotor.

(Rubianus, 2012) melaksanakan penelitian tentang keefektifan model $L C$ - 6 terhadap hasil belajar kimia siswa kelas XI SMA Negeri 1 Makale dari tingkatan motivasi belajar yang berbeda. Penelitian ini telah memperhatikan tingkat motivasi belajar siswa, yaitu yang tinggi, sedang dan rendah. Pada siswa yang motivasinya tinggi, skor hasil rata-rata pos tesnya lebih tinggi 15,9 poin, yang motivasi sedang kenaikan skor rata-rata postes 12,3 poin, yang motivasi rendah peningkatan skor rata-rata postes paling kecil yakni 8,7 poin. Dengan demikian tingkat motivasi siswa mempengaruhi hasil pos tes siswa. Materi hidrolisis garam pada pembelajaran kimia umumnya merupakan konsep-konsep yang abstrak juga melibatkan perhitungan secara matematis. Pada materi ini juga dapat dilakukan kegiatan di laboratorium, sehingga selain hasil belajar ranah kognitif, seharusnya dapat juga diukur hasil belajar ranah psikomotor dan afektif. Disamping itu kualitas proses belajar yang terjadi selama menggunakan model $L C-6$ dan konvensional juga dapat dibandingkan.

Pada penelitian ini disamping menggunakan model pembelajaran $L C$ - 6 pada materi pokok asam-basa, juga diamati peningkatkan kualitas proses dan hasil belajar serta retensi hasil belajar siswa. Hasil belajar yang diukur juga telah meliputi ketiga ranah yaitu: kognitif, psikomotor dan afektif. Kemudian juga mengukur kemampuan mempertahankan dan mengingat kembali materi yang telah diajarkan selama selang waktu 2 minggu dan setelah 4 minggu, baik yang model pembelajaran $L C$ - 6 maupun yang menggunakan model pembelajaran konvensional. Akan tetapi mengingat waktu yang terbatas peneliti belum sempat memberikan pengayaan materi, jadi masih terbatas seperti KTSP 2006. 
Meskipun demikian, dibanding 4 penelitian terdahulu penelitian ini mempunyai beberapa keunggulan, yaitu: 1) Disamping mengukur hasil belajar, penelitian ini juga mengamati kualitas proses pembelajaran, 2) Hasil belajar yang diteliti telah meliputi 3 ranah yaitu: kognitif, afektif dan psikomotor, 3) Diteliti juga retensi hasil belajar siswa selama kurun waktu 2 dan 4 minggu setelah tes hasil belajar diberikan.

Dapat disimpulkan dimuka semua hasil penelitian menunjukkan skor positif pada penggunaan model pembelajaran LC-6 dibandingkan skor yang diperoleh pada pembelajaran yang menggunakan model konvensional.

\section{SIMPULAN DAN SARAN}

\section{Simpulan}

Hasil belajar siswa yang diajar dengan model pembelajaran $L C-6$ lebih baik dari hasil belajar siswa yang diajar dengan model pembelajaran konvensional pada ranah kognitif, psikomotor dan afektif. Retensi hasil belajar siswa yang diajar dengan model pembelajaran $L C-6$ lebih baik dari retensi hasil belajar siswa yang diajar dengan model pembelajaran konvensional untuk tes retensi I dan II. Kualitas proses pembelajaran siswa yang diajar dengan model $L C$ - 6 lebih baik dan kualitas proses pembelajaran siswa yang diajar dengan model pembelajaran konvensional; dan (4) siswa yang diajar dengan menggunakan model LC-6 memberikan respon yang positif terhadap model pembelajaran yang diberikan, sedangkan siswa yang diajar dengan model pembelajaran konvensional memberikan respon yang netral terhadap model pembelajaran yang diberikan.

\section{Saran}

Mengingat penggunaan model pembelajaran $L C$-6 bagi pemula membutuhkan waktu yang lebih lama terutama pada fase engagement dan eksplorasi maka perlu disediakan teks bahan ajar yang sesuai dengan model pembelajaran $L C$ - 6 sehingga proses pembelajaran lebih dapat dimediasi dan lebih terfokus pada kegiatan belajar siswa, sehingga dapat dilaksanakan sesuai dengan waktu yang tersedia. Agar dapat memberikan nuansa yang baru dalam mengajarkan kimia maka disarankan agar para guru kimia menggunakan model pembelajaran yang konstruktivistik, karena hal ini dapat membantu siswa untuk belajar mandiri dan sehingga lebih dapat mengkonstruksi konsep-konsep yang sesuai serta menumbuhkan aktivitas dan kreatifitas berpikir siswa; (3) model pembelajaran $L C$-6 perlu diterapkan pada materi-materi lain yang sesuai, karena model pembelajaran ini mampu meningkatkan prestasi belajar siswa secara signifikan.

\section{DAFTAR RUJUKAN}

Amien, M. (1990). Pemetaan Konsep: Suatu teknik untuk meningkatkan belajar yang bermakna. Mimbar Pendidikan, 2(9), 55-69.

Brown, P. L., \& Abell, S. K. (2007). Examining The Learning Cycle Science and Children. Columbia: Science Education at the University of Missouri.

Budiasih, E., \& Widarti, H. R. (2009). Penerapan Pendekatan Daur Belajar (Learning Cycle) dalam Pembelajaran Matakuliah Praktikum Kimia Analisis Instrumentasi. Jurnal Pendidikan Dan Pembelajaran (JPP), 11(1).

Depdiknas. (2003). Kurikulum 2004 Standar Kompetensi Mata Pelajaran Kimia Sekolah Menengah dan Madrasah Aliyah. Jakarta.

Ibnu, S. (2005). Kimia Analitik I. Malang: Universitas Negeri Malang.

Iskandar, S. M. (2009). Penerapan konstruktivisme dalam pembelajaran kimia di SMU. Media Komunikasi Kimia, 5(2).

Kartini, K. (2007). Keefektifan Pembelajaran Menggunakan Model Pembelajaran Learning Cycle dan Diagram Alir untuk Meningkatkan Hasil Belajar Siswa di SMA Laboratorium Universitas Negeri Malang pada Konsep Stoikhiometri Larutan dan Larutan Penyangga. Universitas Negeri Malang.

Mackinnu, M. (1996). Meningkatkan Kreatifitas dan Ketrampilan Proses Siswa Melalui Metode Sains Teknologi dan Masyarakat. Malang: FMIPA Universitas Negeri Malang.

Maysara, M. (2006). Keefektifan Model Pembelajaran Learning Cycle untuk Meningkatkan Prestasi Belajar Siswa Terhadap Konsep Laju Reaksi pada Siswa. Universitas Negeri Malang.

Nur, M., \& Wikandari, P. R. (2000). Pengajaran berpusat kepada siswa dan pendekatan konstruktivis dalam pengajaran. Surabaya: Unesa.

Pranata, M. (2006). Pengaruh desain pesan multimedia dan tipe literasi terhadap kemampuan retensi dan transfer. Disertasi.

Rubianus, R. (2012). Keefektifan Model Learning Cycle Terhadap Hasil Belajar Siswa dari Tingkatan Motivasi Belajar yang Berbeda. Jurnal Keguruan Dan Ilmu Pendidikan, 1(1), 1-13. 
Sadiqin, I. K., Istyadji, M., \& Winarti, A. (2017). Mengoptimalkan Potensi Otak Kanan Siswa dalam Pembelajaran Kimia. Quantum: Jurnal Inovasi Pendidikan Sains, 8(1), 27-35.

Sagala, S. (2010). Konsep dan makna pembelajaran. Bandung: Alfabeta.

Sardiman, S. (2010). Media Pembelajaran. Jakarta: Rajawali Press.

Sudjana, N. (2014). Penilaian hasil proses belajar mengajar. Bandung: Remaja Rosdakarya.

Suharnan, M. S. (2005). Psikologi kognitif. Surabaya: Srikandi.

Winkel, W. S. (2007). Psikologi Pengajaran. Yogyakarta:Penerbit Media Abadi. 